\title{
Diagnostic usefulness of pregnancy-associated plasma protein-A in suspected pulmonary embolism
}

\author{
Serdar Berk ${ }^{1 *}$, Omer Tamer Dogan ${ }^{1}$, Eylem Itir Aydemir ${ }^{2}$, Asli Bingol ${ }^{1}$, Sefa Levent Ozsahin ${ }^{1}$ and Ibrahim Akkurt ${ }^{1}$
}

\begin{abstract}
Background: The role of biomarkers for prognostication and diagnosis of pulmonary embolism (PE) is increasing. It has been reported that pregnancy-associated plasma protein-A (PAPP-A) can be used as a proatherosclerotic marker. The present study was aimed to evaluate whether PAPP-A levels are helpful in the differential diagnosis of patients presenting with suspected PE.

Methods: 53 consecutive patients evaluated for suspected PE were prospectively enrolled in the study. Serum PAPP-A levels were measured in the blood samples which were taken at admission. Multi-slice computed tomographic angiography was used to verify the diagnosis of PE.
\end{abstract}

Results: PE was detected in 24 out of the 53 patients, while it was excluded in 29 patients by thorax multi-detector computerized tomography scan. No significant difference was detected in mean serum PAPP-A level between groups $(5.72 \pm 0.31 \mathrm{mg} / \mathrm{L}$ vs. $5.67 \pm 0.06 \mathrm{mg} / \mathrm{L}$, respectively).

Conclusions: Serum PAPP-A level has no role in the evaluation for PE.

Keywords: Inflammation, Pulmonary embolism, PAPP-A

\section{Background}

Pulmonary embolism (PE) is an important clinical entity with high mortality and morbidity. Particularly, mortality is determined by hemodynamic status and underlying disease. The role of biomarkers for the prognostication and diagnosis of $\mathrm{PE}$ is increasing [1,2].

The pregnancy-associated plasma protein-A (PAPP-A) is a matrix metalloproteinase which is an activator of insulin-like growth factor-1. The PAPP-A with elevating serum levels by the progression of pregnancy is mainly used as a part of screening tests for Down syndrome [3]. Moreover, it has been reported that its serum level is increased during plaque rupture process in acute coronary syndromes, suggesting that it can be used as a proatherosclerotic marker [4]. The present study was aimed to evaluate whether PAPP-A levels are helpful

\footnotetext{
* Correspondence: serdar.berk@yahoo.com

'Department of Chest Diseases, Medical Faculty of Cumhuriyet University, Sivas, Turkey

Full list of author information is available at the end of the article
}

in the differential diagnosis of patients presented with suspected PE.

\section{Methods}

Overall, 53 consecutive patients presenting to our hospital in the last six months with suspected PE were prospectively enrolled to the study. The study was approved by Local Ethic Committee of the University. All patients gave written informed consent. Demographic characteristics and clinical findings were recorded. The routine laboratory (e.g. complete blood count, liver and kidney function tests, D-dimer and Troponin I measurements, arterial blood gas analysis and ECG) and radiological evaluations (e.g. chest $\mathrm{X}$-ray and thoracic CT scan) were performed to establish or exclude the diagnosis of PE.

Besides, routine laboratory evaluations were performed to establish or exclude the diagnosis of $\mathrm{PE}$, and multi-slice thorax CT angiography was performed for definitive diagnosis. All CT evaluations were performed by using 16slice MDCT scanner (Brilliance iCT, Philips Healthcare, Cleveland $\mathrm{OH}, \mathrm{USA}$ ) and automatic intravenous contrast 
material injections were performed by MEDRAD's Stellant Injection Systems (Stellant, Medrad, Indianola, USA).

Scanning was performed while patients were in a supine position with both arms being next to head, and lasted approximately 10 seconds. The following acquisition parameters were used: $120 \mathrm{kV}$; $200 \mathrm{mAs}$; collimation $16 \times 0.75$; pitch value 0.9 ; and gantry rotation time 0.5 . A scanogram was obtained that primarily involves thoracic outlet and diaphragm. The area from diaphragm to aortic arc was identified as region of interest. A tracker was placed at pulmonary trunk to automatically trigger acquisition when contrast material reached to $120 \mathrm{HU}$ within pulmonary artery. First, the area between aortic arc and diaphragm was scanned with a slice thickness of $2 \mathrm{~mm}$. Then, the area between aortic arc and thoracic outlet was scanned with a slice thickness of $0.5 \mathrm{~mm}$. Non-ionic iodine $(350 \mathrm{mg} / \mathrm{mL})$ was used as contrast material. Axial, coronal and sagittal planes were assessed by volume rendering Maximum Intensity Projection (MIP) and Multiplanar Reformation (MPR) techniques. In these assessments, standard mediastinal $(350 / 40)$ and pulmonary $(-700 / 1000)$ windows were used. The images of multi-slice CT angiography were assessed for presence of embolism in main, lobar, segmental and subsegmental arteries and for sufficiency of vascular contrast enhancement.

Blood samples $(5 \mathrm{ml})$ were drawn into plain tubes to measure PAPP-A levels at presentation. Than samples were centrifuged and sera obtained were stored at $-80^{\circ} \mathrm{C}$ until assays. Before analysis, sera awaited at room temperature. PAPP-A levels were measured by EIA method using ultrasensitive ELISA kit (ELIZEN PAPP-A; Zentech, Angleur, Belgium). Pregnant women, and those with prerenal azotemia, renal failure, liver disease, diabetes, known hypertension and heart diseases were excluded.

\section{Statistical analysis}

The descriptive statistics (mean, standard deviation, frequency) as well as Chi-square and Student's t tests were used in the data analysis.

\section{Results}

On the thorax multi-slice CT angiography, PE was detected in 24 patients $(\mathrm{PE}+)$ (Figure 1), while it was excluded in 29 (PE-) of 53 patients. Out of the 29 patients without PE, 20were affected with pneumonia, 5 with COPD exacerbation, one with Dressler syndrome and onewith empyema, while restrictive pulmonary disorders causing acute respiratory stress was detected in two patients. Mean age was $62 \pm 17$ years in 24 patients with $\mathrm{PE}$, and $63 \pm 15$ years in 29 patients without PE. $48 \%$ of the patients with PE were women, whereas $52 \%$ of those without PE were women. The mean age and sex distribution were similar in both groups $(\mathrm{p}>0.05)$. While cough was more frequent in patients without PE, other clinical, radiological and laboratory

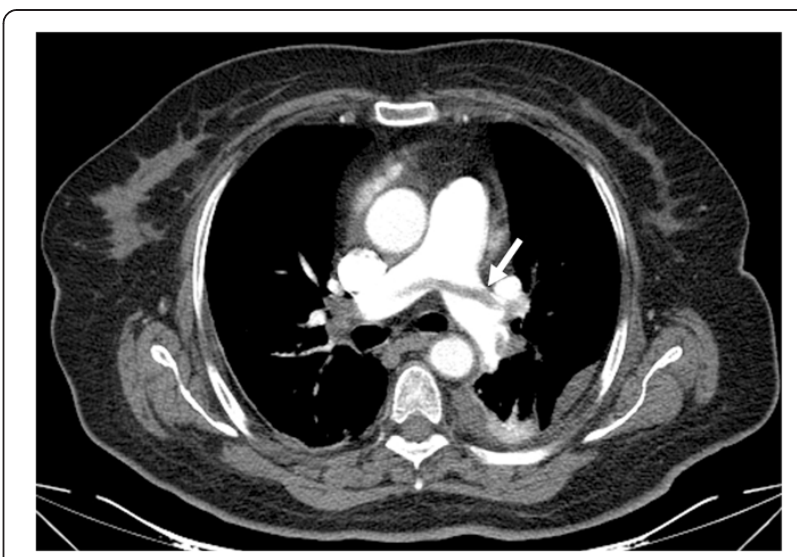

Figure 1 Sixty eight-year-old female patient with pulmonary emboli.

finding were found to be similar in both groups (Tables 1 and 2). The distribution of serum PAPP-A values was similar in both groups (Figure 2). No significant difference was found in mean serum PAPP-A levels between groups $(5.72 \pm 0.31 \mathrm{mg} / \mathrm{L}$ vs. $5.67 \pm 0.06 \mathrm{mg} / \mathrm{L}$, respectively; $\mathrm{p}=0.399)$.

Table 1 Comparison of clinical and radiological findings of the study groups

\begin{tabular}{|c|c|c|c|}
\hline Parameters & $\begin{array}{c}\mathrm{PE}(+) \\
(\mathrm{n}=24) \\
\mathrm{n}(\%)\end{array}$ & $\begin{array}{c}\mathrm{PE}(-) \\
(\mathrm{n}=29) \\
n(\%)\end{array}$ & $p$ \\
\hline Sex (men) & $13(54)$ & $14(48)$ & 0.669 \\
\hline \multicolumn{4}{|l|}{ Symptoms } \\
\hline Shortness of breath & $18(75)$ & $25(86)$ & 0.299 \\
\hline Chest pain & $14(58)$ & $25(86)$ & 0.098 \\
\hline Palpitation & $12(50)$ & $10(34)$ & 0.254 \\
\hline Cough & $11(45)$ & $21(72)$ & $0.049^{*}$ \\
\hline Leg swelling & $8(33)$ & $9(31)$ & 0.858 \\
\hline Hemoptysis & $5(20)$ & $3(10)$ & 0.288 \\
\hline \multicolumn{4}{|l|}{ Physical examination findings } \\
\hline Crackles & $14(58)$ & $22(76)$ & 0.174 \\
\hline Ronchus & $4(17)$ & $7(24)$ & 0.504 \\
\hline Cyanosis & $6(25)$ & $13(44)$ & 0.134 \\
\hline Tachycardia & $5(20)$ & $6(20)$ & 0.990 \\
\hline Tachypnea & $4(17)$ & $10(34)$ & 0.143 \\
\hline \multicolumn{4}{|l|}{ Radiological findings } \\
\hline Infiltration & $14(58)$ & $22(76)$ & 0.174 \\
\hline Cardiomegaly & $16(66)$ & $14(48)$ & 0.179 \\
\hline Linear atelectasis & $7(29)$ & $9(31)$ & 0.883 \\
\hline Pleural effusion & $5(20)$ & $9(31)$ & 0.402 \\
\hline Elevation of the Diaphragm & $3(12)$ & $4(14)$ & 0.890 \\
\hline
\end{tabular}

${ }^{*} \mathrm{p}<0.05$ significant difference.

PE: Pulmonary embolism. 
Table 2 Comparison of laboratory features of the study groups

\begin{tabular}{|c|c|c|c|}
\hline \multirow[t]{2}{*}{ Parameters } & $\mathrm{PE}(+)$ & $\mathrm{PE}(-)$ & \multirow[t]{2}{*}{ p } \\
\hline & Mean \pm SD & Mean \pm SD & \\
\hline Age (year) & $62 \pm 17$ & $63 \pm 15$ & 0.720 \\
\hline $\mathrm{BMI}\left(\mathrm{kg} / \mathrm{m}^{2}\right)$ & $28 \pm 4$ & $27 \pm 3$ & 0.308 \\
\hline Hearth rate (breaths/min) & $88 \pm 15$ & $92 \pm 20$ & 0.511 \\
\hline $\mathrm{SBP}(\mathrm{mmHg})$ & $121 \pm 30$ & $126 \pm 29$ & 0.515 \\
\hline $\mathrm{DBP}(\mathrm{mmHg})$ & $73 \pm 17$ & $75 \pm 12$ & 0.504 \\
\hline Respiratory rate (breaths/min) & $23 \pm 3$ & $26 \pm 4$ & $0.021^{*}$ \\
\hline Body temperature & $36.7 \pm 0.6$ & $36.5 \pm 0.8$ & 0.546 \\
\hline $\mathrm{pH}$ & $7.43 \pm 0.06$ & $7.42 \pm 0.07$ & 0.675 \\
\hline $\mathrm{PaO}_{2}(\mathrm{mmHg})$ & $55.6 \pm 15.2$ & $61.8 \pm 18.1$ & 0.286 \\
\hline $\mathrm{PaCO}_{2}(\mathrm{mmHg})$ & $37.3 \pm 6.3$ & $36.5 \pm 7.6$ & 0.680 \\
\hline $\mathrm{SaO}_{2}(\%)$ & $87.0 \pm 7.5$ & $89.8 \pm 6.6$ & 0.222 \\
\hline $\mathrm{CRP}(\mathrm{mg} / \mathrm{L})$ & $57 \pm 62$ & $81 \pm 92$ & 0.293 \\
\hline WBC $\left(\times 10^{3} / \mu \mathrm{L}\right)$ & $11.6 \pm 5.6$ & $15.3 \pm 14.2$ & 0.239 \\
\hline $\mathrm{Hb}(\mathrm{g} / \mathrm{dl})$ & $13.3 \pm 2.6$ & $13.6 \pm 2.3$ & 0.678 \\
\hline $\mathrm{Ht}(\%)$ & $40.8 \pm 8.3$ & $40.3 \pm 6.6$ & 0.396 \\
\hline $\operatorname{PLT}\left(\times 10^{3}\right)$ & $266 \pm 105$ & $260 \pm 107$ & 0.865 \\
\hline D-Dimer (ng/ml) & $2938 \pm 3471$ & $1968 \pm 3106$ & 0.313 \\
\hline PAPP-A (mlU/ml) & $5.72 \pm 0.31$ & $5.67 \pm 0.06$ & 0.399 \\
\hline
\end{tabular}

$B M I$ : Body mass index, CRP: C-reactive protein, $D B P$ : Diastolic blood pressure, $H b$ : Hemoglobin, $H t$ : Hematocrit, PLT: Platelet, PAPP-A: Pregnancy-associated plasma protein-A, SBP: Systolic blood pressure, SD: Standard deviation, $W B C$ : White blood cells.

${ }^{*} p<0.05$ significant difference.

\section{Discussion}

Pulmonary embolism is characterized by the formation of a blood clot in a vein, which will begin to travel through the circulatory system and will become lodged within the pulmonary arterial system. Clinics, radiology, and laboratory findings in patients with PE are associated with the degree of occlusion of arteries, and the cardiopulmonary reserve of the patient. Dyspnoea, pleuritic chest pain, cough, haemoptysis, mild fever, tachypnea, tachycardia, and crackles are the most common symptoms and signs in patients with PE. Atelectasis, pleural effusion, pulmonary infiltrates, and mild elevation of a hemi diaphragm may be seen on chest X-ray. Elevated D-dimer, leukocytosis, hypoxemia may be seen [5]. These findings are nonspecific and can be seen in pneumonia, pleurisy, acute exacerbation of chronic lung disease, acute coronary syndromes, acute congestive heart failure or pulmonary oedema, pneumothorax, and dissecting or rupturing aortic aneurysm [6]. Richman et al. reported $81 \%$ pneumonia, $7 \%$ aortic aneurysm or dissection, and $7 \%$ mass suggesting undiagnosed malignancy were found in patients whom PE were ruled out by chest computed tomography angiography, in emergency departments patients with symptoms suspicious for PE [7]. Main symptoms and features were shortness of breath, chest pain, crackles, infiltration, and cardiomegaly in patients with or without PE (detected or ruled out by multi-slice $\mathrm{CT}$ angiography), in our study. Routine blood tests and arterial blood gases (ABG) results were not different between groups. Pneumonia (70\%), and acute exacerbation of COPD (5\%) were the main diagnosis in the PE negative group. As revealed in previous studies, symptoms and signs, physical examination, conventional

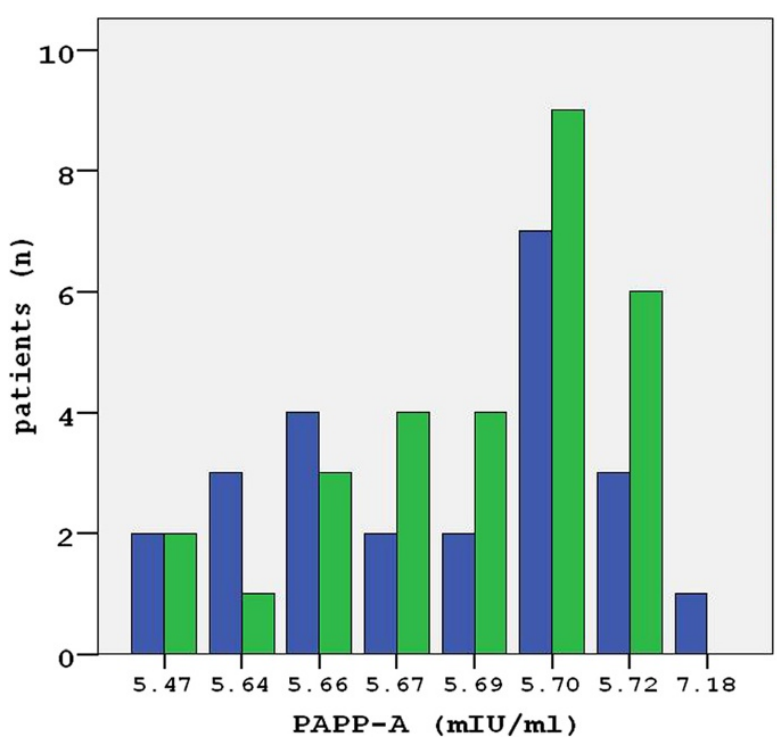

PE (+), $n=24$

PE (-), $n=29$ 
radiography, routine laboratory tests, and ABG examination may not reveal or rule out PE in patients with suspected $\mathrm{PE}$, which is supported by our study.

The pregnancy-associated plasma protein-A (PAPP-A) is a matrix metalloproteinase which is primarily synthesized and released to circulation by placental trophoblasts during pregnancy. It is used for screening of Down syndrome in pregnancy [3]. In a study on vascular smooth muscle cells obtained from human coronary arteries, Bayes-Genis et al. demonstrated that vascular smooth muscles cells are able to synthesize and release PAPP-A. Authors also reported that PAPP-A cause plaque progression and destabilization by contributing inflammatory cytokine release from macrophages and LDL-cholesterol accumulation [4]. In the light of these data, several studies have been performed suggesting that PAPP-A, an inflammatory marker like CRP, may be used in both diagnosis and prognostication of acute coronary syndromes [8-12]. It has been thought that PAPP-A might be a marker of unstable plaque rupture in patients with sudden cardiac death [9]. The elevation of PAPP-A may be an independent predictor of ischemic events [10]. There is a weak correlation between PAPP-A and CK-MB; thus, the elevation of PAPP-A may not be related to necrosis. In acute coronary syndromes, it has been proposed that the disruption of plaque stability by proteolytic enzymes released due to local inflammation is accounted from the rupture of atherosclerotic plaques within vessel in acute coronary syndromes [11]. The inflammation is not only local but also systemic [12]. Liuzzo et al. reported that CRP, the prototype marker of inflammation, was elevated in coronary diseases [13]. On the other hand, CRP may increase in many diseases, especially in pneumonia, as it is a non-specific inflammatory marker.

There are some studies investigating whether serum PAPP-A levels are increased in conditions other than pregnancy and atherosclerotic events. Bulut et al. reported that PAPP-A, as an inflammatory marker, was increased in patients with lung cancer [14]. Again, in another study it has been shown that PAPP-A release might play an important role in the development and progression of lung cancer [15].

In another study, it has been reported that serum PAPP-A level was significantly higher in asthmatic patients when compared with healthy controls and there was a correlation between severity of asthma and serum PAPP-A level [16]. Fialova et al. reported that serum PAPP-A levels were increased in chronic renal diseases in relation to oxidative stress and inflammation [17]. In a study investigating serum PAPP-A levels in 1,448 patients with different disorders but not coronary artery disease, no significant elevation was detected in serum PAPP-A levels across any diseases subgroup. In addition, no correlation was detected between serum PAPP-A level and other inflammatory markers such as NT-proBNP, creatinine or CRP. The PAPP-A might potentially be a specific marker for heart diseases but it seems to have lower specificity in patients without coronary heart disease [18]. However, to our knowledge, there is no study evaluating the relation between PE and PAPP-A in English literature.

In our study, PE was confirmed in 24 out of the 53 patients with suspected PE, while it was excluded in 29 patients. Of the patients in whom PE was excluded, about $70 \%$ had pneumonia. No significant difference was found in serum CRP and PAPP-A levels between the two groups. This can be explained by the presence of inflammation in both conditions. Although there are no sufficient data in this context, we think that our results are in agreement with the literature in general. Lack of healthy control group may be seen as a limitation. However, it would not be useful in the differential diagnosis of PE, even if serum PAPP-A levels are significantly higher than healthy controls.

\section{Conclusions}

In conclusion, serum PAPP-A level has no significant role either to establish the diagnosis or in differential diagnosis in patients with suspected PE.

\section{Competing interests}

The authors declared no potential conflicts of interest with respect to the research, authorship, and/or publication of this article.

\section{Author details}

${ }^{1}$ Department of Chest Diseases, Medical Faculty of Cumhuriyet University, Sivas, Turkey. ${ }^{2}$ Deparment of Statistics, Science Faculty of Cumhuriyet University, Sivas, Turkey.

Received: 14 May 2013 Accepted: 12 July 2013

Published: 31 July 2013

\section{References}

1. Kostrubiec M, Pruszczyk P, Bochowicz A, Pacho R, Szulc M, Kaczynska A, Styczynski G, Kuch-Wocial A, Abramczyk P, Bartoszewicz Z, Berent H, Kuczynska K: Biomarker-based risk assessment model in acute pulmonary embolism. Eur Heart J 2005, 26(20):2166-2172.

2. Tulevski II, ten Wolde M, van Veldhuisen DJ, Mulder JW, van der Wall EE, Büller HR, Mulder BJ: Combined utility of brain natriuretic peptide and cardiac troponin T may improve rapid triage and risk stratification in normotensive patients with pulmonary embolism. Int J Cardiol 2007, 116(2):161-166.

3. Bonno M, Oxvig C, Kephart GM, Wagner JM, Kristensen T, Sottrup-Jensen L, Gleich GJ: Localization of pregnancy-associated plasma protein-A and colocalization of pregnancy-associated plasma protein-A Messenger ribonucleic acid and eosinophil granule major basic protein messenger ribonucleic acid in placenta. Lab Invest 1994, 71(4):560-566.

4. Bayes-Genis A, Schwartz RS, Lewis DA, Overgaard MT, Christiansen M, Oxvig C, Ashai K, Holmes DR Jr, Conover CA: Insulin-like growth factor binding protein-4 protease produced by smooth muscle cells increases in the coronary artery after angioplasty. Arterioscler Thromb Vasc Biol 2001, 21(3):335-341.

5. Yung GL, Fedullo PF: Pulmonary thromboembolic Disease. In Fishman's Pulmonary Diseases and Disorders. 4th edition. Edited by Fishman AP, Elias JA. Philadelphia: McGraw-Hill; 2008:1423-1448.

6. Kostadima E, Zakynthinos E: Pulmonary embolism: pathophysiology, diagnosis, treatment. Hellenic J Cardiol 2007, 48(2):94-107. 
7. Richman PB, Courtney DM, Friese J, Matthews J, Field A, Petri R, Kline JA: Prevalence and significance of nonthromboembolic findings on chest computed tomography angiography performed to rule out pulmonary embolism: a multicenter study of 1,025 emergency department patients. Acad Emerg Med 2004, 11(6):642-647.

8. Buja LM, Willerson JT: Role of inflammation in coronary plaque disruption. Circulation 1994, 89(1):503-505.

9. Biasucci LM, Rizzello V: Pregnancy-associated plasma protein-A: do specific markers of vascular or plaque activation exist, and do we really need them? Clin Chem 2006, 52(6):913-914.

10. Gururajan P, Gurumurthy P, Nayar P, Rao GS, Babu RS, Sarasabharati A, Cherian KM: Pregnancy associated plasma protein-A (PAPP-A) as an early marker for the diagnosis of acute coronary syndrome. Indian Heart J 2012, 64(2):141-145.

11. Heeschen C, Dimmeler S, Hamm CW, Fichtlscherer S, Simoons ML, Zeiher AM: Pregnancy-associated plasma protein-A levels in patients with acute coronary syndromes: comparison with markers of systemic inflammation, platelet activation, and myocardial necrosis. J Am Coll Cardiol 2005, 45(2):229-237.

12. Buffon A, Biasucci LM, Liuzzo G, D'Onofrio G, Crea F, Maseri A: Widespread coronary inflammation in unstable angina. New Engl J Med 2002, 347(1):5-12.

13. Liuzzo G, Biasucci LM, Gallimore JR, Grillo RL, Rebuzzi AG, Pepys MB, Maseri $A$ : The prognostic value of C-reactive protein and serum amyloid $A$ protein in severe unstable angina. N Engl J Med 1994, 331(7):417-424.

14. Bulut I, Coskun A, Ciftci A, Cetinkaya E, Altiay G, Caglar T, Gulcan E: Relationship between pregnancy-associated plasma protein-A and lung cancer. Am J Med Sci 2009, 337(4):241-244.

15. Pan $H$, Hanada $S$, Zhao J, Mao L, Ma MZ: Protein secretion is required for pregnancy-associated plasma protein-A to promote lung cancer growth in vivo. PLoS One 2012, 7(11):e48799.

16. Coskun A, Balbay O, Duran S, Annakkaya AN, Bulut I, Yavuz O, Kurt E: Pregnancy-associated plasma protein-A and asthma. Adv Ther 2007 24(2):362-367.

17. Fialová L, Kalousová M, Soukupová J, Sulková S, Merta M, Jelínková E, Horejsí M, Srámek P, Malbohan I, Mikulíková L, Tesar V, Zima T: Relationship of pregnancy-associated plasma protein-A to renal function and dialysis modalities. Kidney Blood Press Res 2004, 27(2):88-95.

18. Iversen KK, Teisner AS, Teisner B, Kliem A, Bay M, Kirk V, Nielsen H, Boesgaard S, Grande P, Clemmensen P: Pregnancy-associated plasma protein A in non-cardiac conditions. Clin Biochem 2008, 41(7-8):548-553.

doi:10.1186/2049-6958-8-49

Cite this article as: Berk et al.: Diagnostic usefulness of pregnancyassociated plasma protein-A in suspected pulmonary embolism.

Multidisciplinary Respiratory Medicine 2013 8:49.

\section{Submit your next manuscript to BioMed Central and take full advantage of:}

- Convenient online submission

- Thorough peer review

- No space constraints or color figure charges

- Immediate publication on acceptance

- Inclusion in PubMed, CAS, Scopus and Google Scholar

- Research which is freely available for redistribution 